\title{
Keanekaragaman Makrozoobenthos pada Hutan Mangrove yang Direhabilitasi di Pantai Timur Sumatera Utara
}

\author{
Onrizal(1), Fernades SP Simarmata1), dan Hesti Wahyuningsih ${ }^{2)}$ \\ 1)Departemen Kehutanan, Fakultas Pertanian, Universitas Sumatera Utara, Medan \\ ${ }^{2)}$ Departemen Biologi, Fakultas MIPA, Universitas Sumatera Utara, Medan
}

Diterima 27-03-2008

Disetujui 14-01-2009

\begin{abstract}
Macrozoobenthos is a group of important fauna in mangrove ecosystem. Mangrove rehabilitation is required to increase biodiversity and density of fauna, including macrozoobenthos. The aim of this research was to study influence of biotic and abiotic factors to diversity and abundance of macrozoobenthos. The research was conducted at natural and rehabilitated mangrove forest in Percut Sei Tuan, east coastal of North Sumatra. The results showed that density of macrozoobenthos were significantly correlated to the soil texture, soil organic carbon and pH. Besides, macrozoobenthos diversity was mostly influenced by stand basal area, salinity and silt proportion of soil texture.
\end{abstract}

Keywords: macrozoobenthos, mangrove, density, diversity, rehabilitation

\section{PENDAHULUAN}

Mangrove berperan penting dalam ekosistem pesisir, baik secara fisik, biologi, maupun ekonomi, namun kelestariannya terancam akibat tekanan aktivitas manusia (Valiela et al, 2001). Hutan mangrove yang kompak mampu melindungi pantai dari kerusakan akibat tsunami (Istiyanto et al, 2003, Pratikto et al 2002, Dahdouh-Guebas et al, 2005, Onrizal 2005, Sharma 2005). Hasil penelitian Pratikto et al, (2002) dan Istiyanto et al, (2003) menunjukkan bahwa energi gelombang yang sampai di pantai jauh berkurang setelah melewati tegakan mangrove, sehingga pantai aman dari abrasi.

Jaringan anatomi tumbuhan mangrove mampu menyerap bahan polutan, misalnya jenis Rhizophora mucronata dapat menyerap 300 ppm Mn, 20 ppm Zn, 15 ppm Cu (Darmiyati et al, 1995), sedangkan daun Avicennia marina mampu mengakumulasi $\mathrm{Pb} \geq 15 \mathrm{ppm}$, $\mathrm{Cd} \geq 0,5 \mathrm{ppm}, \mathrm{Ni} \geq 2,4$ ppm (Saepulloh 1995). Sehingga vegetasi mangrove mampu mengurangi pencemaran.

Hutan mangrove berperan penting bagi perikanan laut, yakni sebagai tempat pemijahan (spawning), pengasuhan (nursery), dan pembesaran atau mencari makan (feeding). Berbagai jenis burung dan satwa lainnya menjadikan hutan mangrove sebagai habitat

*Telp: 0618220605

Email: onrizal03@yahoo.com yang penting, baik untuk keseluruhan maupun sebagian siklus hidupnya. Nontji (1993), menyatakan bahwa jatuhan serasah mangrove merupakan sumber bahan organik penting dalam rantai pakan (food chain) di lingkungan perairan yang bisa mencapai 7-8 ton/ha/ tahun.

Kerusakan mangrove menyebabkan menurunnya fungsi lindung, biologi dan pada akhirnya nilai ekonomi yang bisa dicapai juga berkurang. Oleh karena itu, upaya pemulihan kondisi mangrove harus dilakukan secara terencana dengan memperhatikan faktor lingkungannya (Stevenson et al, 1999; Kairo et al, 2001; Lewis III 2004). Keberhasilan rehabilitasi mangrove dapat meningkatkan keanekaragaman dan populasi biota laut, termasuk golongan invertebrata. Invertebrata merupakan komponen penting dalam ekosistem mangrove dan menyediakan berbagai sumber makanan bagi manusia dan hewan lain yang lebih tinggi tingkat tropiknya (Fitriana 2005). Invertebrata yang berupa organisme benthos (organisme yang hidup atau tinggal dalam sedimen) memproduksi berjuta larva dalam bentuk meriplankton yang mendukung populasi ikan dan menjaga keseimbangan ekosistem dengan membuat lubang, sehingga air dan udara bisa masuk ke dalam tanah (Somodihardjo \& Soeroyo 1988; Fitriana 2005). Selain itu, benthos berperan penting sebagai salah satu hewan pengurai jatuhan serasah mangrove 
(Soemodihardjo 1977, Soemodihardjo \& Kastoro 1977, Somodihardjo \& Soeroyo 1988).

Hasil penelusuran terhadap publikasi dan prosiding seminar ekosistem mangrove di Indonesia (Soemodihardjo, Nontji \& Djamali 1979, Soemodihardjo et al, 1984, 1991, 1995, Soerianegara 1987, Soemodihardjo, Romimohtarto \& Suhardjono 1999, MOFEC \& JICA 1999), penelitian benthos umumnya pada hutan mangrove alami, sedangkan pada hutan mangrove yang direhabilitasi sangat terbatas, yakni hanya pada hutan mangrove yang direhabilitasi di Bali (Fitriana 2005). Oleh karena itu, penelitian untuk mengkaji faktor-faktor biotik dan abiotik yang mempengaruhi keanekaragaman dan kelimpahan makrozoobenthos pada hutan mangrove yang direhabilitasi dan mangrove alami di Sumatera Utara sangat penting dilakukan sebagai salah satu pertimbangan dalam kegiatan rehabilitasi mangrove yang rusak di masa mendatang.

\section{BAHAN DAN METODE}

Prosedur kerja. Penelitian lapangan dilakukan di hutan mangrove Desa Tanjung Rejo Kecamatan Percut Sei Tuan Kabupaten Deli Serdang Sumatera Utara (Gambar 1) pada bulan November-Desember 2006. Penelitian laboratorium dilakukan di Laboratorium Ekologi F-MIPA dan Laboratorium Sentral FP USU pada bulan Januari 2007.

Tiga blok dipilih secara acak dari keseluruhan blok penanaman yang ada, sedangkan pada hutan alam

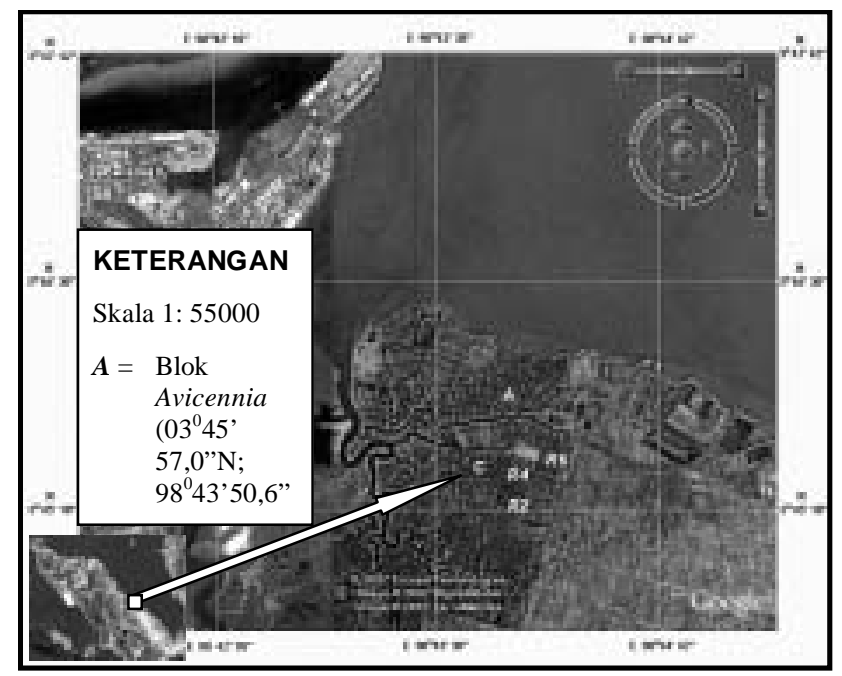

Gambar 1. Peta lokasi penelitian makrozoobenthos hutan mangrove di Percut Sei Tuan, pantai timur Sumatera Utara (sumber peta: http://www.googleearth.com). dipilih dua blok contoh. Pada hutan tanaman blok terpilih adalah umur 2, 4, dan 6. Hutan mangrove tanaman merupakan mangrove yang direhabilitasi melalui program rehabilitasi hutan dan lahan oleh Departemen Kehutanan bekerjasama dengan kelompok tani setempat pada tahun 2000, 2002, dan 2004. Pada setiap blok kemudian ditentukan petak-petak contoh. Petak contoh tersebut merupakan petak yang ditanami oleh Rhizophora apiculata dan Rhizophora mucronata pada hutan tanaman, sedangkan pada hutan alam, petak contoh ditumbuhi secara alami oleh Avicennia sp. dan Ceriopssp.

Data tegakan diambil pada setiap petak contoh dengan menggunakan petak contoh bujur sangkar, 10 $x 10 \mathrm{~m}^{2}$ untuk pohon berdiameter $\geq 10 \mathrm{~cm}$ dan $5 \times 5 \mathrm{~m}^{2}$ untuk pohon berdiameter $<10 \mathrm{~cm}$ yang diletakkan secara acak dalam blok contoh. Jumlah petak contoh pada setiap blok contoh adalah 3 buah dan dianggap sebagai ulangan. Pada setiap petak contoh, diukur tinggi dan diameter tegakan..

Contoh substrat diambil dengan membenamkan pipa paralon sedalam $20 \mathrm{~cm}$ pada masing-masing petak contoh. Substrat pada masing-masing petak contoh diaduk dan dicampur merata, kemudian diambil $200 \mathrm{~g}$ contoh substrat. Contoh substrat dianalisis di Laboratorium Sentral FP USU untuk pengukuran peubah fisika dan kimia substrat. Parameter fisika yang diukur meliputi tekstur dan tipe substrat, sedangkan parameter kimia yang diukur adalah $\mathrm{pH}$ tanah dan kandungan karbon organik. Pengukuran komposisi tekstur dilakukan dengan cara pipet, sedangkan pengukuran kandungan karbon organik menggunakan metode Walkey \& Black (Suin 2002). Contoh air diambil pada masing-masing petak contoh pengamatan untuk mengetahui kadar salinitasnya. Pengukuran salinitas dilakukan dengan menggunakan hand refractometer.

Data makrozoobentos diambil sebanyak lima kali pada setiap petak contoh pada saat surut dengan dengan membenamkan kotak berukuran $20 \times 20 \times 20$ $\mathrm{cm}^{3}$ pada substrat. Seluruh substrat yang berada di kotak tersebut diangkat dengan sekop, selanjutnya disimpan dalam kantung plastik. Pemisahan antara makrozoobentos dengan substrat dilakukan dengan bantuan air, serta saringan berukuran $1 \mathrm{~mm}$. Makrozoobentos yang telah terpisah dari substratnya dimasukkan ke dalam larutan formalin 4\% (Suin 2002). 
Contoh organisme makrozoobentos diidentifikasi di Laboratorium Ekologi FMIPA USU.

Analisis Data. Analisis data vegetasi untuk mengetahui nilai penting menggunakan rumus Cox (1981). Penetapan kelas tekstur tanah dengan menggunakan bantuan segitiga USDA, terhadap komposisi substrat yang diperoleh. Hasil kandungan karbon organik dikategorikan berdasarkan persentasenya, yaitu sangat rendah jika kandungan karbonnya $<1,00$; rendah 1-2,00; sedang 2,01-3,00 dan tinggi $>3,00$

Kelimpahan makrozoobenthos dihitung mengikuti rumus Suin (2002), dengan frekuensi kehadiranan dihitung dengan rumus Krebs (1985). Indeks ShannonWiener $\left(H^{\prime}\right)$ digunakan untuk menghitung keanekaragaman makrozoobenthos. Selain itu, data makrozoobenthos juga mencakup indeks keseragaman $(\mathcal{J})$, indeks dominansi $(C)$, indeks penyebaran/dispersi jenis (Id) dan indeks kesamaan jenis (IS) (Ludwig \& Reynolds 1988).

Analisis data gabungan mencakup uji perbandingan rata-rata dan uji non parametrik. Perbedaan kelimpahan dan keanekaragaman di antara dua komunitas yaitu hutan tanaman dan hutan alam menggunakan uji Mann-Whitney. Korelasi antara kelimpahan dan keanekaragaman makrozoobentos dengan variabel kerapatan tegakan, kandungan pasir, debu, liat, karbon organik, salinitas, dan $\mathrm{pH}$ dilakukan dengan uji Spearman.

\section{HASIL DAN PEMBAHASAN}

Kondisi Tegakan. Pada hutan mangrove yang direhabilitasi dengan jenis $R$. apiculata dan $R$. mucronata pada semua umur tersebar secara merata ( $\mathrm{F}>75 \%$ ). Pada hutan mangrove alami untuk komunitas Avicennia hanya disusun oleh satu jenis, yaitu $A$. officinalis yang tersebar secara merata, sedangkan pada komunitas Ceriops, juga dijumpai jenis lain, yaitu A. officinalis, Brugueira gymnorrhiza dan Excoecaria agallocha. Pada komunitas Ceriops, jenis C. tagal dan $A$. officinalis tersebar secara merata dengan jenis dominannya adalah $C$. tagal.

Diamater dan tinggi tanaman pada hutan mangrove hasil rehabilitasi terus meningkat seiring dengan bertambahnya umur tanaman (Gambar 2). Sementara itu, pada komunitas hutan mangrove alami, diameter dan tinggi pohon tertinggi dijumpai pada komunitas Avicennia.

Kerapatan tegakan pada lokasi pengamatan disajikan pada Gambar 3. Kerapatan tegakan tertinggi terdapat pada petak pengamatan Rhizophora 4 tahun yaitu 8.133 pohon/Ha, sedangkan kerapatan tegakan terendah pada petak komunitas alam Avicennia yaitu 1.433 pohon/Ha.

Karakteristik Substrat Tanah. Di seluruh petak pengamatan, kandungan debu dalam substrat lebih dominan dibandingkan kandungan pasir, debu, dan liat (Gambar 4). Berdasarkan perbandingan tersebut, didapatkan hasil bahwa substrat mangrove di petakpetak pengamatan pada umumnya adalah lempung. Pada Rhizophora 2 tahun, Rhizophora 4 tahun, Rhizophora 6 tahun dan Avicennia memiliki kelas tekstur substrat lempung, sedangkan pada petak Ceriops memiliki kelas tekstur lempung berdebu. Kelas tekstur substrat pada lokasi pengamatan merupakan habitat yang cukup baik bagi pertumbuhan mangrove. Onrizal \& Kusmana (2004), menyatakan bahwa Rhizophora, tumbuh pada tanah berlumpur halus, sedangkan Avicennia menyukai tanah yang bercampur lumpur dan pasir, serta Ceriops menyukai substrat berlumpur dan liat.

Kandungan karbon organik di lokasi penelitian termasuk tinggi (Gambar 4), kecuali pada petak pengamatan Ceriops yang termasuk dalam kategori sedang dengan kandungan sebesar $2,42 \%$. Kandungan C-organik terbesar pada petak Rhizophora 6 tahun dengan kandungan sebesar $8,72 \%$. Sumber utama bahan organik tanah berasal dari daun, ranting, cabang, batang dan akar tumbuhan. Kandungan organik yang terdapat pada daun, sebagai penyumbang organik tanah. Rendahnya kandungan organik pada petak Ceriops kemungkinan disebabkan oleh kerusakan pada komunitas Ceriops pada hutan alam karena penebangan, sehingga suplai serasahnya rendah. Hal ini sejalan dengan hasil penelitian Onrizal et al, (2007) pada lokasi yang sama bahwa produktivitas serasah

Tabel 1. Nilai pH tanah dan salinitas air pada petak pengamatan. 


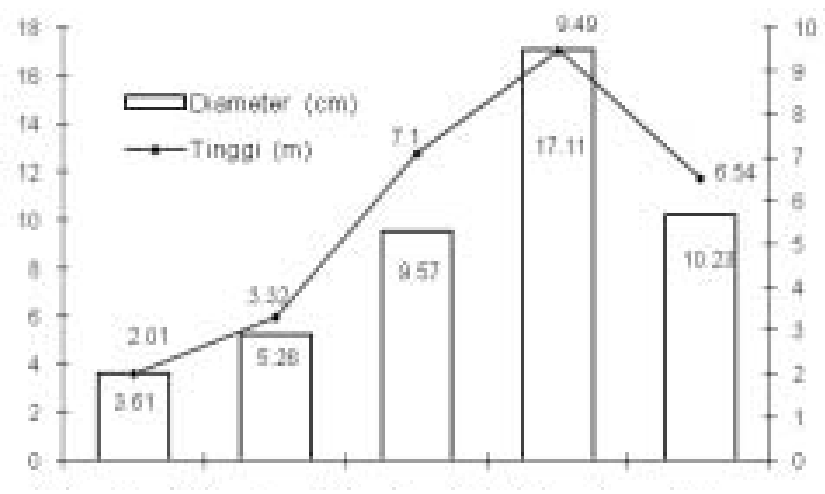

Gambar 2. Diameter rata-rata dan tinggi rata-rata tegakan pada lokasi pengamatan

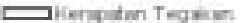
palinential

$\rightarrow-$ Los In $2 \mathrm{H}$ He)
Gambar 3. Kerapatan dan luas bidang dasar (Lbds) tegakan pada lokasi pengamatan

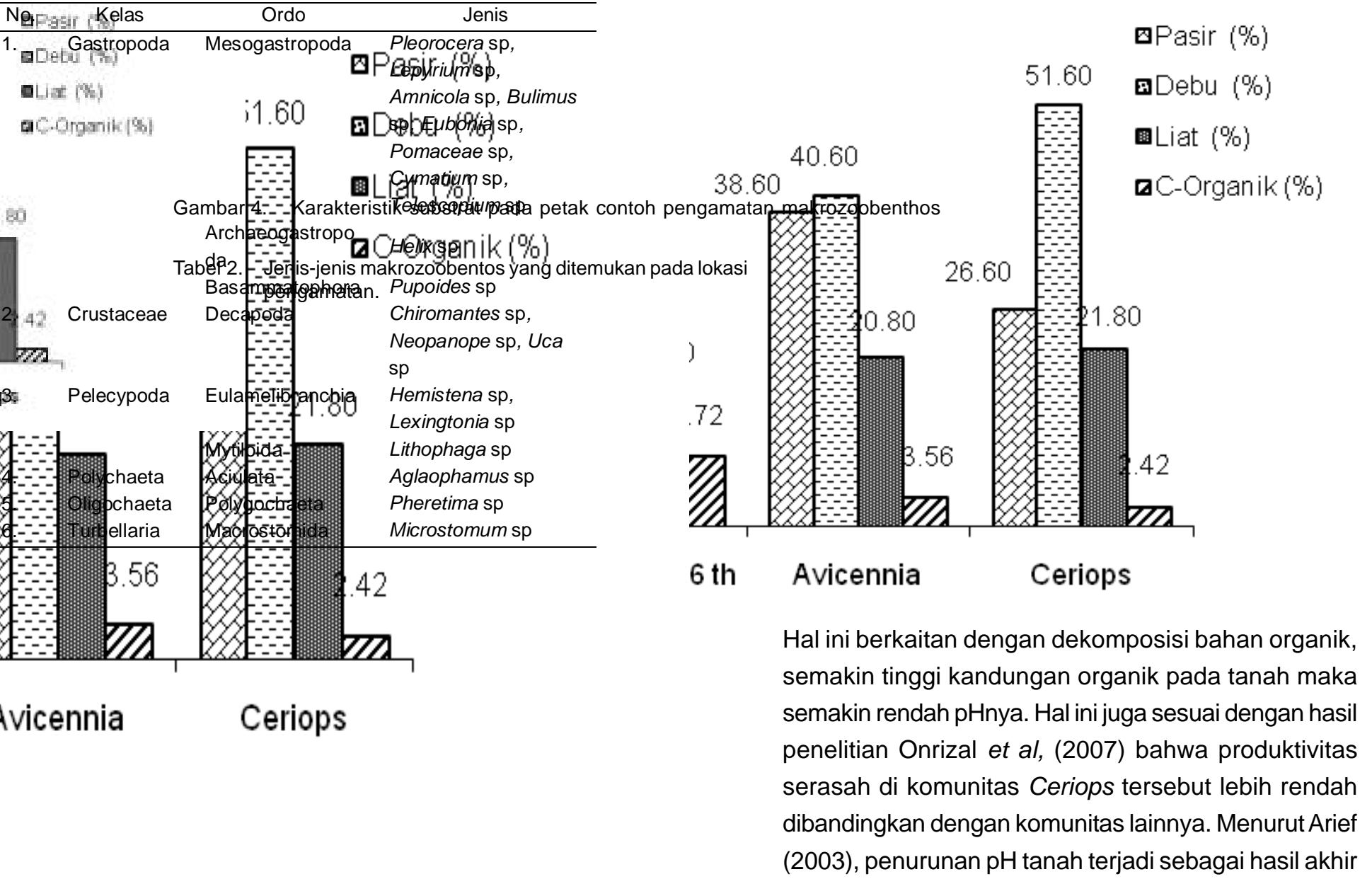


Tabel 3. Penyebaran makrozoobentos yang ditemukan di lokasi pengamatan.

Tabel 4. Karakterisitik komunitas makrozoobenthos pada lokasi penelitian.

\begin{tabular}{llccccc}
\hline \multirow{2}{*}{ No. } & \multirow{2}{*}{ Karakteristik Komunitas } & \multicolumn{3}{c}{ Hutan Tanaman } & \multicolumn{3}{c}{ Hutan Alam } \\
\cline { 3 - 6 } & & $\mathrm{R} 2$ & $\mathrm{R} 4$ & $\mathrm{R} 6$ & $\mathrm{~A}$ & $\mathrm{C}$ \\
\hline 1. & Jumlah jenis & 6 & 9 & 12 & 10 & 11 \\
2. & Kelimpahan $/ \mathrm{m}^{2}(D)$ & 121,67 & 116,67 & 136,67 & 138,33 & 100,00 \\
3. & Indeks keanekaragaman $\left(H^{\prime}\right)$ & 1,65 & 2,02 & 2,19 & 2,02 & 2,22 \\
4. & Indeks keseragaman $\left(\mathrm{J}^{\prime}\right)$ & 0,92 & 0,92 & 0,88 & 0,88 & 0,93 \\
5. & Indeks dominansi (C) & 0,22 & 0,15 & 0,15 & 0,16 & 0,13 \\
6. & Pola penyebaran (Id) & 3,07 & 2,02 & 2,07 & 2,30 & 1,65 \\
\hline
\end{tabular}

proses dekomposisi yang menghasilkan asam-asam dominan.

Salinitas pada petak pengamatan berada pada kisaran 18-19,67\% (Tabel 1). Onrizal \& Kusmana (2004) menyebutkan bahwa tumbuhan mangrove tumbuh subur di daerah estuaria dengan salinitas $10-30 \%$. Salinitas yang sangat tinggi (>35\%) berpengaruh buruk pada vegetasi mangrove, karena dampak dari tekanan osmotik yang negatif.

Karakteristik komunitas makrozoobenthos. Komposisi dan penyebaran makrozoobenthos. Hasil pengamatan menunjukkan bahwa terdapat 19 jenis makrozoobenthos yang berasal dari enam kelas yaitu Gastropoda, Crustaceae, Pelecypoda (Bivalvia), Polychaeta, Oligochaeta, dan Turbellaria. Penyebaran tertinggi dijumpai pada hutan tanaman umur 6 tahun (12 genus), kemudiaan diikuti oleh komunitas Ceriops alami (11 genus), dan komunitas Avicennia alami (10 genus) (Tabel 2). Penyebaran lengkap makrozoobenthos yang dijumpai seperti pada Tabel 3 .

Berdasarkan Tabel 3 terlihat bahwa kelas Crustaceae dan Gastropoda ditemukan di seluruh komunitas tegakan (khususnya Chiromantes sp. dari kelas Crustaceae dan Pleorocera sp. dari kelas Gastropoda). Kedua jenis makrozoobenthos tersebut dapat hidup dengan baik pada lokasi pengamatan dengan tingkat adaptasi yang tinggi. Penyebaran kelas Crustaceae dan Gastropoda tersebut sejalan pula dengan komposisi masing-masing kelas pada setiap jenis tegakan dibandingkan dengan kelas-kelas lain seperti Pelecypoda, Polychaeta, Oligochaeta dan Turbellaria. Kelas Pelecypoda hanya terdapat pada hutan alam Avicennia dan Ceriops. Hal ini disebabkan kelas Pelecypoda bersifat menetap pada suatu tempat dan tidak dapat bergerak aktif, sehingga kelas ini mempunyai toleransi yang lebih terbatas dibandingkan kelas Gastropoda dan Crustaceae. 
Tabel 5. Hasil perhitungan indeks kesamaan dan ketidaksamaan jenis makrozoobentos.

\begin{tabular}{|c|c|c|c|c|c|c|}
\hline \multirow{7}{*}{ 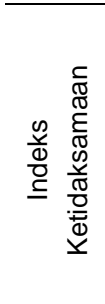 } & \multicolumn{6}{|c|}{ Indeks Kesamaan } \\
\hline & Jenis Tegakan & $\begin{array}{r}\text { Rhizophora } \\
2 \text { tahun }\end{array}$ & $\begin{array}{r}\text { Rhizophora } \\
4 \text { tahun }\end{array}$ & $\begin{array}{r}\text { Rhizophora } \\
6 \text { tahun }\end{array}$ & Avicennia & Ceriops \\
\hline & Rhizophora 2 th & $\mid / / / / / I / I / /$ & 0,800 & 0,555 & 0,375 & 0,471 \\
\hline & Rhizophora 4 th & 0,200 & /I//I/I/I/I/I & 0,762 & 0,421 & 0,400 \\
\hline & Rhizophora 6 th & 0,445 & 0,238 & /II/I/I/I/I/I & 0,545 & 0,609 \\
\hline & Avicennia & 0,625 & 0,579 & 0,455 & /IIIIIIIIII/ & 0,476 \\
\hline & Ceriops & 0,529 & 0,600 & 0,391 & 0,524 & //I/I/I/I//I \\
\hline
\end{tabular}

Tabel 6. Hasil uji Mann-Whitney kelimpahan makrozoobentos antar blok pengamatan

Pada Rhizophora 2 tahun sebagian besar terdiri dari kelas Gastropoda (66\%), Rhizophora 4 tahun komposisi Gastropoda (49\%) hampir sama dengan kelas Crustaceae (47\%) dan Rhizophora 6 tahun dikuasai oleh kelas Crustaceae (54\%). Pada hutan alam Avicennia komposisi terbanyak kelas Gastropoda (79\%), sedang Signifikas

(79\%), sedangken terbanyak adalala ketlars Crustacenar $(A 7 \%)$. 6 tahun

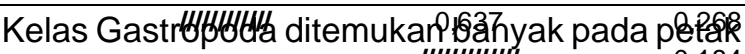
pengamatan, kemungkinan disebabkan tingginya ba, 0 han 184 organik yang merupakan sumber makanan bagi Gastropoda. Hal ini dapat dilihat pada kandungan Corg tanah pada petak pengamatan yang umumnya tergolong tinggi kecuali pada petak Ceriops. Menurut Handayani et al, (2001), gastropoda merupakan organisme yang mempunyai kisaran penyebaran yang luas di substrat berbatu, berpasir, maupun berlumpur. Selain itu gastropoda memiliki cangkang tubuh yang kuat yang membuatnya mampu bertahan dari gerusan air pasang surut. Nybakken (1988), menyatakan bahwa hewan yang hidup di lingkungan pasir harus dilengkapi dengan cangkang yang kuat, mampu bergerak bersama butiran pasir, atau memendam dalam di bawah permukaan untuk menghindari penggerusan pada saat air pasang surut.

Kelas Crustaceae memiliki penyebaran yang luas disebabkan kemampuan osmoregulasi, cangkang yang kuat, dan fisiologi tubuh yang memungkinkannya memakan dedaunan mangrove sehingga kebutuhan makanannya lebih terpenuhi. Menurut Nybakken (1988), Crustaceae memiliki pengaturan osmosis yang berkembang dengan baik. Kombinasi antara permeabilitas tubuh yang sangat terbatas karena adanya kerangka luar, dengan kemampuan yang menonjol untuk mengatur konsentrasi ion cairan tubuhnya, mungkin merupakan alasan keberhasilannya hidup di estuaria. Selain itu menurut Suwignyo et al,

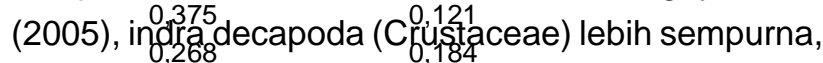
sehingga, 82emungkinkano 0 tompok Crustaceae ini

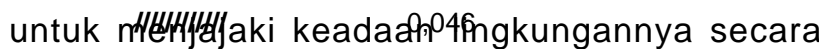
berkesinambungan, misalnya untuk menentukan tempat berlindung, mencari makan atau pasangan, menghindar dari predator atau lingkungan tidak nyaman.

Kelas Polychaeta dan Pelecypoda ditemukan sedikit pada lokasi pengamatan disebabkan kemampuannya dalam osmoregulasi. Menurut Nybakken (1988), pada binatang bertubuh lunak tertentu, misalnya cacing Polychaeta, mekanisme pengaturan osmosis dikembangkan, tetapi responnya relatif lambat. Moluska bivalvia biasanya merupakan osmoregulator yang buruk dan tanggap terhadap penurunan salinitas yang drastis dengan menutup diri di dalam cangkangnya.

Cacing Polychaeta Aglaophamus sp. sangat menyukai habitat yang berpasir. Hal ini dapat dilihat bahwa jenis ini hanya didapatkan pada petak Rhizophora 6 tahun yang substratnya memiliki kandungan pasir relatif lebih tinggi dari petak yang lain. 
Tabel 7. Nilai korelasi Spearman pada masing-masing aspek dengan kelimpahan maupun keanekaragaman makrozoobentos.

Polychaeta merupakan pemakan deposit dan filter feeder. Menurut Nybakken (1988), polychaeta makan dengan cara menggali substrat, mencerna, dan menyerap bahan organik dan mengeluarkan bahan yang tidak dicerna melalui anus.

Kelas Oligochaeta hanya ditemukan pada beberapa petak. Hal ini mungkin disebabkan kelas ini sangat memerlukan naungan. Oligochaeta ditemukan pada Rhizophora 6 th dan Ceriops yang memiliki tajuk yang lebat, sehingga lebih menaungi substrat di bawahnya. Hal ini sesuai dengan yang dinyatakan oleh Thomlinson (1986) bahwa Rhizophora dan Ceriops memiliki tajuk lebih kompak dan tebal dibandingkan dengan Avicennia. Oligochaeta jenis Pheretima sp. (cacing tanah) juga merupakan filter feeder. Menurut Purwati (2005) sistem pencernaan cacing tanah sangat adaptif dengan aktivitas makan dan menggali tanah. Cacing menelan tanah (termasuk residu dekomposisi organik dalam tanah) atau residu dan sisa tanaman pada permukaan tanah.

Penyebaran atau keberadaan makrozoobentos di hutan mangrove tidak lepas dari kemampuan hewan tersebut bertahan terhadap air pasang. Hal ini dapat dilihat pada makrozoobentos kelas Gastropoda dan Crustaceae. Gastropoda naik dan menempel ke batang dan ranting pohon pada saat air pasang. Pada Crustaceae, ada beberapa kepiting yang memiliki kemampuan memanjat pohon mangrove. Hal ini dilakukan makrozoobentos untuk menghindari peningkatan salinitas akibat air pasang.

Kondisi hutan mangrove yang diamati tidak mengalami pencemaran, hal ini ditunjukkan tidak ditemukannya jumlah Polychaeta yang melimpah pada petak-petak pengamatan. Kesimpulan ini berdasarkan pendapat Priyono (2004), bahwa cacing dari jenis Polychaeta bisa menjadi indikator terjadinya pencemaran yang representatif di kawasan mangrove. Apabila pada kawasan mangrove ditemukan jumlah cacing yang melimpah, bisa dikatakan kawasan tersebut tercemar oleh bahan pencemar tertentu.

Pengaruh pencemaran secara keseluruhan akan menyebabkan terjadinya dominansi oleh organisme yang tahan terhadap perubahan lingkungan yaitu jenis Bivalvia sehingga terbentuk zonasi (Zaman 2001). Pada penelitian ini tidak ditemukan zonasi/dominansi yang begitu berarti pada kelas Pelecypoda (bivalvia) yang menunjukkan kondisi lingkungan yang cukup stabil.

\section{Kelimpahan dan Keanekaragaman} Makrozoobenthos. Kelimpahan makrozoobentos tertinggi dijumpai pada komunitas Avicennia yaitu sebanyak 138,33 individu $/ \mathrm{m}^{2}$, sedangkan yang terendah pada lokasi Ceriops yaitu sebanyak 100 individu $/ \mathrm{m}^{2}$ (Tabel 3). Indeks keanekaragaman makrozoobentos di keseluruhan petak pengamatan termasuk dalam kategori sedang $\left(1<\mathrm{H}^{\prime}<3,32\right)$ dengan kisaran indeks $1,65-2,22$. Hal ini berarti pada semua komunitas produktivitasnya cukup tinggi, kondisi ekosistem seimbang dan tekanan ekologi sedang. Indeks keanekaragaman terendah pada petak Rhizophora 2 tahun dengan nilai 1,650, sedangkan indeks keanekaragaman tertinggi pada petak Ceriops dengan nilai 2,217 (Tabel 4). Indeks keanekaragaman yang tinggi pada Ceriops kemungkinan disebabkan variasi atau keheterogenan vegetasi yang mendiami lokasi tersebut, yaitu terdapat 4 jenis pohon mangrove, sehingga menciptakan rentang toleransi yang tinggi bagi jenis-jenis makrozoobentos.

Indeks keseragaman makrozoobentos di keseluruhan petak pengamatan termasuk tinggi. Nilai indeks keseragaman di keseluruhan petak berkisar 0,880,92 . Nilai indeks keseragaman tertinggi terdapat pada petak Ceriops yaitu 0,92, sedangkan nilai indeks keseragaman terendah terdapat pada petak Avicennia dan hutan tanaman umur 4 tahun yaitu 0,88 (Tabel 4). Indeks keseragaman mendekati nilai 1,00 berarti semua contoh yang ada di petak tersebut memiliki jumlah masing-masing jenis organisme yang sama.

Nilai indeks dominansi di keseluruhan petak termasuk rendah dengan kisaran 0,125-0,215 (Tabel 4). Rendahnya dominansi jenis menandakan adanya kekayaan jenis tinggi dan merata. Hal ini juga berarti makrozoobentos di lokasi pengamatan memanfaatkan sumberdaya hampir secara merata. 
Makrozoobentos di keseluruhan petak pengamatan memiliki pola penyebaran mengelompok (Id >1) dengan kisaran indeks 1,652-3,065 (Tabel 4). Hal ini menandakan adanya penyebaran sumberdaya untuk mendukung kehidupan makrozoobentos yang mengelompok pada seluruh lokasi pengamatan.

Indeks kesamaan yang tertinggi terdapat antara komunitas Rhizophora 2 tahun dan Rhizophora 4 tahun yaitu sebesar 0,800 (sangat mirip). Indeks kesamaan terendah terdapat antara komunitas Rhizophora 2 tahun dan Avicennia yaitu sebesar 0,375 (tidak mirip). Kisaran indeks kesamaan yang tinggi (sangat mirip) antar komunitas Rhizophora 2 tahun dengan Rhizophora 4 tahun dan Rhizophora 4 tahun dengan Rhizophora 6 tahun, yaitu dengan kisaran 0,762-0,800 (Tabel 5), disebabkan persamaan jenis tegakan yang mendiami komunitas-komunitas tersebut.

Uji Mann-Whitney. Hasil uji Mann-Whitney menunjukkan tidak adanya perbedaan kelimpahan dan keanekaragaman di antara hutan alam dan hutan tanaman. Namun antar blok di hutan alam, yakni komunitas Avicennia dan komunitas Ceriops terdapat perbedaan kelimpahan makrozoobentos antar blok Avicennia dan Ceriops, sedangkan antar blok pengamatan di hutan tanaman tidak ada perbedaan (Tabel 6).

Analisis Korelasi Spearman. Hasil uji korelasi Spearman antara kelimpahan dan keanekaragaman makrozoobentos dengan aspek-aspek yang diamati disajikan pada Tabel 7. Kelimpahan makrozoobentos berkorelasi paling besar terhadap pasir (positif) dan debu (negatif) dan berbanding lurus dengan dengan kandungan pasir yang berarti semakin tinggi kandungan pasir maka kelimpahan makrozoobentos akan meningkat. Hal ini sesuai dengan pendapat Arief (2003), bahwa pasir dibutuhkan dalam kehidupan makrobentos, yakni untuk memperbaiki aerasi (menyatu dengan debu) ketika menyusup ke dalam substrat. Kandungan tekstur substrat lainnya seperti debu dan liat menunjukkan korelasi negatif, semakin rendah kandungan debu dan liat maka kelimpahan makrozoobentos akan meningkat. Liat banyak menekan perkembangan dan kehidupan makrobentos, karena partikel-pertikel liat sulit ditembus (Arief 2003). Hasil penelitian ini menunjukkan bahwa kandungan karbon organik berbanding lurus dengan kelimpahan makrozoobentos mengingat bahan organik sangat dibutuhkan oleh makrozoobentos (Tabel 7).

Salinitas berbanding lurus dengan kelimpahan makrozoobenthos (Tabel 7). Menurut Arief (2003), perubahan salinitas sangat berpengaruh terhadap perkembangan beberapa jenis makrobentos. Penurunan kadar salinitas mengakibatkan kematian beberapa jenis makrobentos, sedangkan $\mathrm{pH}$ tanah berbanding terbalik dengan kelimpahan makrozoobentos (Tabel 7). Arief (2003), menyatakan makrozoobentos pada umumnya sangat peka terhadap keasaman tinggi.

Luas bidang dasar (Lbds) tegakan memiliki korelasi positif terhadap kelimpahan makrozoobentos. Semakin besar luas bidang dasar tegakan maka semakin tinggi kelimpahan makrozoobentosnya. Kerapatan tegakan memiliki pengaruh negatif terhadap kelimpahan makrozoobentos. Hal ini dapat dilihat pada petak Avicennia yang memiliki kerapatan rendah, ternyata memiliki kelimpahan makrozoobentos yang tinggi terutama dari kelas gastropoda yang mendominasi di petak tersebut. Hal ini disebabkan kelas ini tidak membutuhkan naungan, namun beberapa jenis makrozoobentos lainnya membutuhkan naungan seperti Crustaceae dan Oligochaeta.

Hasil uji korelasi Spearman untuk kerapatan tegakan dengan kelimpahan makrozoobentos yang dominan yaitu Crustaceae (kepiting) dan Gastropoda (siput) menunjukkan kerapatan tegakan berkorelasi positif $(0,800)$ terhadap kelimpahan kepiting dan sebaliknya berkorelasi negatif $(-0,300)$ terhadap kelimpahan siput. Hal ini menunjukkan semakin rapat tegakan maka semakin tinggi kelimpahan kepiting dan sebaliknya semakin rendah kerapatan tegakan maka kelimpahan siput semakin meningkat.

Korelasi yang terjadi pada keanekaragaman makrozoobentos tidak terlalu besar dan signifikan. Keanekaragaman makrozoobentos memiliki korelasi terbesar pada kandungan debu (positif) dan salinitas (negatif). Kandungan pasir dan salinitas berbanding terbalik terhadap keanekaragaman. Kandungan liat, kerapatan tegakan dan luas bidang dasar tegakan berbanding lurus terhadap keanekaragaman makrozoobentos. C-org dan $\mathrm{pH}$ tanah tidak memiliki korelasi dengan keanekaragaman makrozoobentos. Korelasi aspek-aspek tersebut terhadap 
keanekaragaman lebih dipengaruhi oleh toleransi berbagai jenis makrozoobentos yang berbeda-beda.

Dari uji ini disimpulkan bahwa kelimpahan makrozoobentos lebih dipengaruhi oleh keadaan substrat tanah yaitu tekstur, $\mathrm{pH}$ tanah dan kandungan karbon. Sebaliknya keanekaragaman diduga dipengaruhi oleh toleransi masing-masing jenis makrozoobentos terhadap keadaan lingkungan, seperti luas bidang dasar, salinitas, kandungan debu tanah dan interaksinya terhadap organisme lainnya.

\section{KESIMPULAN}

Indeks keanekaragaman makrozoobenthos meningkat dengan kelimpahan yang cenderung meningkat seiring dengan bertambahnya umur tanaman mangrove yang direhabilitasi. Terdapat 19 jenis makrozoobentos, yang berasal dari enam kelas yaitu Gastropoda, Crustaceae, Pelecypoda, Polychaeta, Oligochaeta dan Turbellaria. Indeks keanekaragaman makrozoobentos termasuk kategori sedang yang menunjukkan kondisi ekosistem seimbang dan tekanan ekologi sedang. Keanekaragaman makrozoobentos dipengaruhi oleh toleransi masingmasing jenis terhadap keadaan lingkungan dan interaksinya terhadap organisme lainnya. Kelimpahan makrozoobentos lebih dipengaruhi oleh keadaan substrat tanah yaitu tekstur, $\mathrm{pH}$ tanah dan kandungan karbon yang merupakan dampak dari bertambahnya umur tanaman.

\section{UCAPAN TERIMA KASIH}

Penulis mengucapkan terima kasih kepada Ketua Laboratorium Ekologi FMIPA dan Ketua Laboratorium Sentral FP USU atas izinnya menggunakan fasilitas laboratorium untuk identifikasi makrozoobenthos, dan analisis fisik-kimia substrat.

\section{DAFTAR PUSTAKA}

Abdunnur. 2002. Analisis model brocken stick terhadap distribus kelimpahan spesies dan ekotipologi komunitas makrozoobentos di Perairan Pesisir Tanjung Sembilan Kalimantan Timur. (http://www.unmul.ac.id/dat/pub/lemlit/ No.2/01.pdf). (4 Februari 2007).

Arief, A. 2003. Hutan Mangrove: Fungsi dan Manfaatnya. Yogyakarta: Penerbit Kanisius.

Cox, G.W. 1981. Laboratory Manual of General Ecology. United States of America: William C. Brown Company Publisher.

Dahdouh-Guebas, F., L.P. Jayatissa, D. Di Nitto, J.O. Bosire, D. Lo Seen, \& N. Koedam. 2005. How effective were mangroves as a defence againts the recent tsunami? Curr. Bio. 15: R443-R447.
Darmiyati, M., C. Kusmana dan E.N. Dahlan, 1995. Akumulasi logam berat (Mn, Zn, Cu) pada Rhizophora mucronata Lamk. di hutan tanaman mangrove Cilacap. Duta Rimba 31: 17178.

Fitriana, Y.R. 2005. Keanekaragaman dan kemelimpahan makrozoobentos di hutan mangrove hasil rehabilitasi Taman Hutan Raya Ngurah Rai Bali. Biodiversitas 7: 64-69.

Handayani, S.T, B. Suharto, Marsoedi. 2001. Penentuan status kualitas perairan sungai brantas hulu dengan biomonitoring makrozoobentos: tinjauan dari pencemaran bahan organik. http://www.digilib.brawijaya.ac.id/virtual_library/ m l g warintek/P d f \% $20 \mathrm{Material/}$ Biosain\%20Edisi\%20April\%202001\%20(Edisi\%201)/ penentuan\%20status\%20kualitas.pdf. (5 Maret 2007).

Istiyanto, D.C., S.K. Utomo, \& Suranto. 2003. Pengaruh Rumpun Bakau terhadap Perambatan Tsunami di Pantai. Makalah pada Seminar Nasional Mengurangi Dampak Tsunami: Kemungkinan Penerapan Hasil Riset. Yogyakarta, 11 Maret 2003.

Kairo, J.G., F. Dahdouh-Guebas, J. Bosire, \& N. Koedam. 2001. Restoration and management of mangrove systems a lesson for and from the East African region. South African J. Bot. 67: 383-389.

Krebs, C.J.1985. Ecological methodology. New York: Harper and Row Publisher.

Lewis III, R.R. 2005. Ecological engineering for succesfull management and restoration of mangrove forests. Ecological Engineering 24: 403-418.

Ludwig, J.A., \& J.F. Reynolds. 1988. Statistical ecology: a primer on methods and computing. New York: John Wiley \& Sons.

MOFEC \& JICA. 1999. Proceeding of Seminar on the Development of Sustainable Mangrove Management. Ministry of Forestry and Estate Crops and Japan International Cooperation Agency. Jakarta, 29 September 1999. Jakarta: Ministry of Forestry and Estate Crops (MOFEC) and Japan International Cooperation Agency (JICA).

Nontji, A. 1993. Laut nusantara. Jakarta: Penerbit Djambatan.

Nybakken, J. W. 1988. Biologi Laut Suatu Pendekatan Ekologis. Jakarta: PT. Gramedia.

Onrizal \& C. Kusmana. 2004. Ekologi dan Manajemen Mangrove. (Buku Ajar). Medan: Jurusan Kehutanan Fakultas Pertanian Universitas Sumatera Utara.

Onrizal, C. Aprilliana \& D. Suryanto. 2007. Produktivitas serasah hutan mangrove di pantai timur Sumatera Utara. Makalah pada Seminar Nasional Asosiasi Akademisi Perguruan Tinggi Seluruh Indonesia (ASASI). Agustus 2007. Bogor: ASASI.

Onrizal. 2005. Hutan mangrove selamatkan masyarakat di pesisir utara Nias dari Tsunami. Warta Konservasi Lahan Basah 13 : 5-7.

Pratikto, W.A., Suntoyo, K. Simbodho, Sholihin, Taufik, \& D. Yahya. 2002. Perencanaan Perlindungan Pantai Alami untuk Mengurangi Resiko terhadap Bahaya Tsunami. Makalah Lokakarya Nasional Pengelolaan Ekosistem Mangrove. Jakarta, 6-7 Agustus 2002. Jakarta: Departemen Kelautan dan Perikanan (DKP).

Priyono, A. 2004. Binatang-binatang mangrove Jepara. http:// www.penulislepas.com/more.php?id=282 0 - 11 _ 0 M. Maret 2007)

Purwati, A. 2005. Cacing Tanah Menyuburkan Tanah. http:// www.beritabumi.or.id/ berita3.php?idberita=316. (05 Maret 2007).

Saepulloh, C. 1995. Akumulasi Logam Berat (Pb, Cd, Ni) pada Jenis Avicennia marina di Hutan Lindung Angke Kapuk DKI Jakarta. Skripsi Sarjana Kehutanan. Bogor: Fakultas Kehutanan IPB.

Sharma, D. 2005. The tsunami and the mangroves. Dollars \& Sense 260: 14-15.

Soemodihardjo, S \& Soeroyo. 1988. Komunitas mangrove di Pulau Kangean. Oseana 14: 111-122.

Soemodihardjo, S. \& W. Kastoro. 1977. Notes on the Terebralia palustris (Gastropoda) from the coral island in the Jakarta Bay area. Mar. Ind. 18: 131-148. 
Soemodihardjo, S. 1977. Beberapa segi biologi hutan payau dan tinjauan singkat komunitas mangrove Pulau Pari. Oseana 3: 24-23.

Soemodihardjo, S., A. Nontji \& A. Djamali. 1979. Prosiding Seminar Ekosistem Mangrove di Jakarta. Jakarta, 27 Februari - 1 Maret 1978. Jakarta: Lembaga Ilmu Pengetahuan Indonesia.

Soemodihardjo, S., I. Soerinegara, M. Sutisna, K. Kartawinata, Supardi, N. Naamin, \& H. Al Rasyid. 1984. Prosiding Seminar II Ekosistem Mangrove di Baturaden. jakarta, 3-5 Agustus 1982. Jakarta: IImu Pengetahuan Indonesia.

Soemodihardjo, S., K. Romimohtarto, \& Suhardjono. 1999 Prosiding Seminar VI Ekosistem Mangrove di Pekanbaru, Lembaga IImu Pengetahuan Indonesia, Jakarta 15-18 Agustus 1998.

Soemodihardjo, S., P. Wiroatmodjo, S. Bandijono, M. Sudomo, \& Suhardjono. 1995. Prosiding Seminar V Ekosistem Mangrove di Jember, 3-6 Agustus 1994. Jakarta: Lembaga llmu Pengetahuan Indonesia.

Soemodihardjo, S., S. Hardjowigeno, N. Naamin, O.S.R. Ongkosongo, \& M. Sudomo. 1991. Prosiding Seminar IV Ekosistem Mangrove di Bandar Lampung. Lembaga IImu Pengetahuan Indonesia. Jakarta, 7-9 Agustus 1990.
Soerinegara, I., S. Adisoemarto, S. Soemodihardjo, S. Hardjowigeno, M. Sudomo, \& O.S.R. Ongkosongo. 1987. Prosiding Seminar III Ekosistem Mangrove di Denpasar, 3-8 Agustus 1986. Jakarta: Lembaga IImu Pengetahuan Indonesia.

Stevenson, N.J., R.R. Lewis, \& P.R. Burbridge. 1999. Disused shrimp ponds and mangrove rehabilitation. An international Prespective on Wetland Rehabilitation. Kluwer Academic Publisher. pp. 272-297.

Suin, N.M. 2002. Metoda ekologi. Padang: Penerbit Universitas Andalas.

Suwignyo, S, B. Widigdo, Y. Wardiatno \& M. Krisanti. 2005. Avertebrata air. Jilid 1 \& 2. Jakarta: Penebar Swadaya.

Thomlinson, P.B. 1986. The botany of mangroves. London: Cambridge University Press.

Valiela, I., J.L. Bowen, \& J. K. York. (2001). Mangrove forest: one of the world's threatened major tropical environments. Bioscience 51: 807-815.

Zaman, B. 2001. Pengaruh buangan air limbah PLTU terhadap keberadaan hewan makrobentos. Studi kasus: perairan pantai Semarang, Jawa Tengah. http://digilid.ampl.or.id/ detail.php?kode $=424 \&$ row $=5 \&$ tp=pustaka\&ktg=tesis\&kd_link=. (5 Maret 2007). 